\title{
Dialectology Applied to Literature: General and Specific Bibliography on the Works of D. H. Lawrence
}

Consuelo Montes Granado

Universidad de Salamanca

D. H. Lawrence can undoubtedly be included in that group of English authors whose literary production has been subjected to prolific criticism. In spite of this, the secondary sources lack dialectally-oriented investigation, which would be useful in linguistic critical studies, and specially in the analysis of dialogues in the vernacular introduced by Lawrence in some of his novels, short stories, poems and plays, set in his region, the Midlands. It is the aim of this paper to provide a bibliography that could serve this purpose. The bibliographical items on the list below include general and specific dialectal studies, dictionaries of dialect, slang and idioms, and the few titles that, at a lexical and/or a grammatical level, focus on the non-standard variety encountered in his works or on the dialect spoken in his native county, Nottinghamshire, the bordering one of Derbyshire and the Erewash valley separating them. It is here where Eastwood, the village where he was born and grew up, is situated.

Allen, Harold, and Michael D. Linn, eds. Dialect and Language Variation. London: Academic Press, Harcourt Brace Jacovitch, 1986.

Anderson, Peter M. A Structural Atlas of the English Dialects. London: Croom Helm, 1987.

Barry, H. V. «The Morphemic Distribution of the Definite Article in Contemporary Regional English,» in Martyn F. Wakelin, ed., pp. 164-68.

Brook, G. L., English Dialects. London: André Deutsch, 1965.

. The Language of Dickens. London: André Deutsch, 1970.

Brown, Roger, and Albert Gilman. «The Pronouns of Power and Solidarity,» in Thomas A. Sebeok, ed. Style in Language. Cambridge, Mass.: The Massachusetts Institute of Technology Press, 1960, pp. 253-76.

Chambers, J. K., and Peter Trudgill. Dialectology. Cambridge: Cambridge University Press, 1980.

David, Lawrence M. English Dialectology: An Introduction. Alabama: The University of Alabama Press, 1983.

Dean, Christopher: «Some Consonantal Elements in Northern Dialects.» Joumal of Linguistics, 12 (1966), 9-23. 
Duncan, Pauline. «Forms of the Feminine Pronoun in Modern English Dialects,» in Martyn F. Wakelin, ed., pp. 182-200.

Edwards, V. K., P. Trudgill, and B. Weltens. The Grammar of English Dialect: A Survey of Research. London: Economic and Social Research Council, 1984.

Ekwall, Eilert. A History of Modern English Sounds and Morphology. Alan Ward, ed. and trans. Oxford: Basil Blackwell, 1975.

Ellis, Alexander J. English Dialects: Their Sounds and Homes. London: Routledge, 1980. Evans, William, «'You' and 'Thou' in Northen England,» South Atlantic Bulletin, 34 (1966), 17-21 (también en Papers in Language Variation, David Shores, and Carole P. Hines, eds. Albama: University of Alabama Press, 1977, pp. 93-102).

Francis, W. N. Dialectology: An Introduction. London: Longman, 1983.

Gerard, David E. «Glossary of Eastwood Dialect Words Used by D. H. Lawrence in His Poems, Plays and Fiction.» The D. H. Lawrence Review, 1 (1968), 215-37.

- «A Glossary of Nottinghamshire Dialect and Mining Terms,» in $A$ D. $H$. Lawrence Handbook. Keith Sagar, ed. Manchester: Manchester University Press, 1982, pp. $165-76$.

Gimson, A. C. An Introduction to the Pronunciation of English. London: Edward Arnold, 1981.

Glauser, Beat. «Linguistic Atlases and Generative Phonology,» en John M. Kirk, Stewart Sanderson, and J. D. A. Widdowson, eds., pp. 113-29.

Green, Jonathan. The Dictionary of Contemporary Slang. London: Pan Books, 1984.

Henderson, B. L. K. A Dictionary of English Idioms: Part I, Verbal Idioms. London: James Blackwood and Co., 1962.

. A Dictionay of English Idiom: Part II, Colloquial Phrases. London: James Blackwood and Co., 1964.

Hirooka, Hideo. «Verbal and Pronominal Forms in English Dialects» Studies in English Literature (Tokyo), 45 (1969), 181-92.

Hughes, Arthur, and Peter Trudgill. English Accents and Dialect: An Introduction to Social and Regional Varieties of British English. London: Edward Arnold, 1980.

Jones, Daniel. Everyman's Pronouncing Dictionary. A. C. Gimson, ed. and rev. London: J. M. Dent and Sons, 1980.

Kirk, John M., Stewart Sanderson, and J. D. A. Widdowson, eds. Studies in Linguistic Geography. London: Croom Helm, 1985.

Montes Granado, Consuelo. D. H. Lawrence: el dialecto en sus novelas. Salamanca: Ediciones Universidad de Salamanca, 1990.

Orton, H. Survey of English Dialects: Introduction. Leeds: E. J. Arnold, 1962.

, and M. Barry, eds. The West Midland Counties, in Survey of English Dialects:

The Basic Material. Vol. II. Leeds: E. J. Arnold, 1969-71.

, and W. Halliday, eds. The Six Northern Counties and the Isle of Man, in Survey

of English Dialects: The Basic Material. Vol. I. Leeds: E. J. Arnold, 1962-3. and P. M. Tilling, eds. The East Midland Counties and East Anglia, in Survey of

English Dialects: The Basic Material. Vol. III. Leeds: E. J. Arnold, 1969-71. and M. F. Wakelin, eds. The Southern Counties, in Survey of English Dialects:

The Basic Material. Vol. IV. Leeds: E. J. Arnold, 1967-68.

, Stewart Sanderson, and John Widdowson, eds. The Linguistic Atlas of England.

London: Humanities Press, Croom Helm, 1978.

, and N. Wright. A Word Geography of England. London: Seminar Press, 1974. 
Partridge, Eric. Smaller Slang Dictionary. London: Routledge and Kegan Paul, 1980. . The Penguin Dictionary of Historical Slang. Abridged by Jacqueline Simpson. Harmondsworth: Penguin, 1982. . A Dictionary of Slang and Unconventional English. Paul Beale, ed. 8th rev. ed. London: Routledge and Kegan Paul, 1984.

Petyt, K. M. The Study of Dialect: An Introduction to Dialectology. London: André Deutsch, 1980.

Phythian, B. A. Concise Dictionary of English Slang. London: Hodder and Stoughton, 1986.

Rohrer, Fritz. «The Border between the Northen and North-Midland Dialects in Yorkshire.» Transactions of the Yorkshire Dialect Society, 8 (1950), 29-37.

Russ, Charles V. J. «The Geographical and Social Variation of English in England and Wales,» in Richard W. Bailey and Görlach Manfied, eds. English as $A$ World Language. Ann Arbor: University of Michigan Press, 1982, pp. 11-55.

Scollins, Richard, and John Titford. Ey Up Mi Duck. 2 vols. Ilkeston: Scollins and Titford, 1976.

Simpson, John. The Concise Oxford Dictionary of Proverbs. Oxford: Oxford University Press, 1985.

Skeat, Walter W. English Dialects. Cambridge: Cambridge University Press, 1911.

Strang, Barbara M. H. A History of English. London: Methuen, 1974.

Trudgill, Peter, ed. Language in the British Isles. Cambridge: Cambridge University Press, 1984.

Wakelin, Martyn F., ed. Patterns in the Folk Speech of the British Isles. London: The Athlone Press of the University of London, 1972. 1977.

English Dialects: An Introduction. 2nd rev. ed. London: The Athlone Press, . «Rural Dialects in England,» in Peter Trudgill, ed., pp. 70-93.

Wales, Kathleen M. «Thou and You in Early Modern English: Brown and Gilman Re-Appraised.» Studia Linguistica, 37 (1983), 107-25.

Wells, J. C. «Local Accents in England and Wales.» Journal of Linguistics, 6 (1970), 231-52.

. Accents of English 1: An Introduction. Cambridge: Cambridge University Press, 1982. 1982.

. Accents of English 2: The British Isles. Cambridge: Cambridge University Press, . «English Accents in England,» in Peter Trudgill, ed., pp. 55-69.

Wright, Joseph. The English Dialect Dictionary. 6 vols. Oxford: Oxford University Press, 1898-1905.

The English Dialect Grammar, in The English Dialect Dictionary. Vol. VI. Oxford: Oxford University Press, 1981, pp. 1-82.

Wright, Peter. «Coal-Mining Language: A Recent Investigation,» in Martyn F. Wakelin, ed., pp. 32-49.

The Derbyshire Drawl. Dalesman Books, 1975.

The Notts Matter. Dalesman Books, 197 